\title{
Sosialisasi Prinsip Green Chemistry untuk Meningkatkan Kesadaran Akan Bahaya Limbah Kimia Terhadap Lingkungan pada Mahasiswa Prodi Pendidikan Kimia FKIP UNRAM
}

\author{
Syarifa Wahidah Al Idrus ${ }^{1 *}$, Mutiah ${ }^{1}$, Rahwmawati ${ }^{1}$, Eka Junaedi ${ }^{1}$, Yunita Arian Sani Anwar ${ }^{1}$ \\ ${ }^{1}$ Program Studi Pendidikan Kimia, FKIP, Universitas Mataram, Mataram Indonesia
}

DOI: https://doi.org/10.29303/jpmsi.v3i2.135

Citation: Idrus, S. W. A., Mutiah, M., Rahmawati, R., Junaedi, E., Anwar, Y. A. S. 2021. Sosialiasi Prinsip Green Chemistry untuk Meningkatkan Kesadaran Akan Bahaya Limbah Kimia Terhadap Lingkungan pad Mahasiswa Prodi Pendidikan Kimia FKIP UNRAM. Jurnal Pengabdian Masyarakat Sains Indonesia (JPMSI). 3(2):246-252.

\author{
Article history \\ Received: July $30^{\text {th }} 2021$ \\ Revised: September $20^{\text {th }} 2021$ \\ Accepted: November $02^{\text {th }} 2021$ \\ *Corresponding AuthorSyarifa \\ Wahidah Al Idrus, Study \\ Program of Chemistry \\ Education, University of \\ Mataram, Mataram, Indonesia \\ Email: \\ Syarifaidrus@unram.ac.id
}

\begin{abstract}
Abstrak: Pengabdian ini bertujuan untuk memberikan sosialisasi tentang prinsip green chemistry pada mahasiswa prodi kimia FKIP UNRAM. Pelaksanaan dilakukan secara online karena kondisi pandemi. Kegiatan ini diharapkan dapat menambah pengetahuan mahasiswa calon guru kimia tentang bahaya dan usaha yang dapat dilakukan untuk mengurangi limbah kimia. Kegiatan ini diawali dengan pemberian pertanyaan tentang pengetahuan awal green chemistry. Langkah selanjutnya pemberian materi tentang prinsip, manfaat dan aplikasi green chemistry pada kehidupan sehari hari. Selanjutnya peserta diminta memodifikai panduan praktikum yang ada menjadi panduan praktikum berbasis green chemistry. Kemampuan awal peserta tentang green chemistry beragam, peserta yang berasal dari semester yang lebih tinggi sebagian besar pernah membaca tentang green chemistry. Peserta yang berada pada semester V dan VII memberikan hasil yang lebih baik daipada peserta semester I dan III dalam hal memodifikasi panduan praktikum berbasis green chemistry. Hasil kegiatan menunjukkan antusias mahasiswa sangat tinggi dalam melaksanakan semua tahapan kegiatan. Mereka berharap sebagai calon guru mereka dibekali dengan workshop untuk membuat panduan praktikum berbasis green chemistry. Berdasarkan hasil evaluasi akhir, peserta memberikan respon positif terhadap kegiatan yang telah dilakukan.
\end{abstract}

Kata kunci: Sosialiasai, Prinsip Green Chemistry, Limbah Kimia, Lingkungan

\section{Pendahuluan}

Guru merupakan pilar utama dalam membentuk konsep awal pemahaman siswa tentang fenomena yang terjadi disekitar. Guru kimia akan melakukan pendekatan yang sesuai dengan materi yang diajarkan, salah satunya praktikum. Hakikat pembelajaran sains seperti kimia membutuhkan keterampilan minds on dan hands on (Praktikum), (Astuti, 2015). Metode praktikum akan melibatkan laboratorium dan zat zat kimia. Pentingnya praktikum pada materi kimia tidak akan menghilangkan dampak dari penggunaan zat zat kimia terhadap lingkungan.
Pengenalan bahaya zat kimia terhadap siswa sebegai generasi yang akan datang adalah peran guru. Pendidikan kimia memiliki peran sentral dalam pendidikan untuk pembangunan berkelanjutan. (Burmeister, M., et al., 2012). Pembangunan berkelanjutan pada bidang Pendidikan kimia disebut dengan kimia berkelanjutan. Kimia berkelanjutan dapat terwujud salah satunya dengan menerapkan prinsip green chemistry.

Green chemistry merupakan salah satu konsep pemikiran kimia yang dikembangkan dalam Pendidikan untuk ikut serta dalam proses pembangunan berkelanjutan. Kimia hijau disebut juga kimia berkelanjutan digunakan untuk 
Idrus et al, Jurnal Pengabdian Masyarakat Sains Indonesia 2021, 3 (2):246-252 DOI: https://doi.org/10.29303/ipmsi.v3i2.135

merancang produk dan prosedur kimia yang mengurangi pembentukan zat kimia berbahaya. Proses merancang produk dan prosedur kimia yang aman akan menggunakan prinsip green chemistry (Anastas, 2001).

Prinsip kimia hijau sangat dibutuhkan dalam semua proses yang ada kaitannya dengan zat kimia, seperti proses percobaan di laboratorium. Penggunaan bahan kimia berpotensi menghasilkan limbah yang berbahaya bagi lingkungan. Sekolah sebagai pengguna laboratorium dapat menerapkan prinsip kimia hijau (Aubrecht, dkk, 2015), dan penerapan kimia hijau mulai dikembangkan dalam kurikulum kimia (Karpudewan, 2015). Proses pengintegrasian prinsip green chemistry dalam Pendidikan disebut green chemistry education.

\section{Menurut}

Haack,dkk

(2005),

pengintegrasian dan implementasi 12 prinsip green chemistry dalam kurikulum dan pembelajaran disebut sebagai green chemistry education. Hal ini dilakukan dengan harapan dapat mengembangkan kesadaran lingkungan peserta didik sejak dini. Pendidikan kimia memiliki peran sentral dalam pendidikan untuk pembangunan berkelanjutan khususnya kimia berkelanjutan (Burmeister, M., dkk., 2012). Proses penanaman prinsip green chemistry dilakukan mulai dari calon guru kimia yang akan turun langsung menjadi guru kimia.

Penanaman konsep green chemistry bisa dilakukan pada setiap matakuliah di prodi pendidikan kimia, baik yang teori atau praktikum. Sampai saat ini konsep Green Chemistry belum dikenalkan dalam semua proses pembelajaran di Prodi Pendidikan Kimia Universitas Mataram. Hampir semua mata kuliah pada prodi Kimia membutuhkan praktikum. Sehingga semua mata kuliah membutuhkan laboratorium dan bahan bahan kimia. Dan hampir semua limbah bahan kimia berbahaya bagi lingkungan. Melihat kondisi ini sangat diharapkan mahasiswa program studi Pendidikan kimia perlu pemahaman tentang prinsip green chemistry. Kemampuan awal green chemistry yang dimiliki mahasiswa prodi pendidikan kimia sebagian besar berkategori rendah $(<50 \%)$ (Al idrus, dkk, 2020).

Beberapa faktor yang menjadi penyebab antara lain mahasiswa belum mengetahui tentang konsep green chemistry. Kondisi ini sangat bertolak belakang dengan kondisi mahasiswa yang saat ini banyak melakukan praktikum mandiri. Praktikum mandiri akan sangat berbahaya bagi mahasiswa jika tidak mengenal konsep kimia hijau.
e-ISSN $: 2715-2537$

p-ISSN : 2715-2545

Rendahnya pengetahuan awal tentang prinsip green chemistry menjadi perhatian tim pengabdian. Mahasiswa prodi Pendidikan kimia selain terjun langsung di laboratorium kimia dalam setiap matakuliah di kampus, mereka juga merupakan calon guru kimia. Kondisi ini membuat tim pengabdian mempunyai ide untuk memberikan sosialisasi tentang prinsip green chemistry kepada mahasiswa prodi Pendidikan kimia FKIP UNRAM. Sosialisasi ini juga diharapkan bisa meningkatkan kompetensi calon guru kimia. Peningkatan mutu pendidikan dapat dicapai melalui beberapa cara, antara lain melalui peningkatan kualifikasi tenaga kependidikan, pelatihan dan pendidikan, atau dengan memberikan kesempatan kepada tenaga kependidikan lewat pelatihan terkendali (Anonimous, 2003).

\section{Metode}

Metode pelaksanaan kegiatan berupa sosialisasi. Kegiatan sosialisasi prinsip green chemistry pada mahasiswa kimia FKIP UNRAM dilakukan dengan langkah-langkah sebagai berikut.

\section{a. Berkoordinasi dengan HMPS Pendidikan Kimia.}

Tim pengabdian berkoordinasi dengan pengurus HMPS Pendidikan Kimia FKIP UNRAM berkaitan dengan kegiatan sosialisasi. Hal utama yang didiskusikan tentang peserta mahasiswa, jadwal pelakanaan dan model pelaksanaan secara online, mengingat kondisi masih pandemic. Pengurus HMPS diharapkan dapat membantu tim pengabdian untuk menyiapkan mahasiswa yang akan menjadi peserta sosialisai.

\section{b. Mengukur kemampuan awal peserta sosialisai}

Kegiatan ini diawali dengan pemberian pertanyaan pertanyaan yang berkaitan dengan prinsip green chemistry. Hal ini dilakukan untuk mengetahui kemampuan awal peserta sebelum sosialisasi.

\section{c. Sosialisasi prinsip green chemistry}

Sosialisasi prinsip green chemistry diberikan dengan metode ceramah yang dilakukan oleh tim pengabdian secara bergantian.

1. Ceramah

Materi pertama yang diberikan adalah penjelasan prinsip green chemistry dan tentang 
Idrus et al, Jurnal Pengabdian Masyarakat Sains Indonesia 2021, 3 (2):246-252 DOI: https://doi.org/10.29303/ipmsi.v3i2.135

awal munculnya prinsip green chemistry. Pada materi pertama ini dijelaskan ke 12 prinsip green chemistry.

Materi ke 2, menjelaskan tentang manfaat green chemistry. Materi ini menjelaskan manfaat dari green chemistry sehingga peerta sosialisai semakin tertarik mempelajari tentang green chemistry.

Materi ke 3. Membahas tentang pengawasan penerapan kimia hijau di Indonesia. Jadi proses pemanfaatan kimia hijau di Indonesia akan diadakan pengawasan. Hal ini dilakukan untuk melihat sejauh mana penerapan kimia hijau dapat mengurani pencemaran dan kerusakan lingkungan.

Materi ke 4, membahas tentang penerapan prinsip green chemistry yang sudah dilakukan di dunia. Sebagai upaya menambah wawasan peserta sosialisasi.

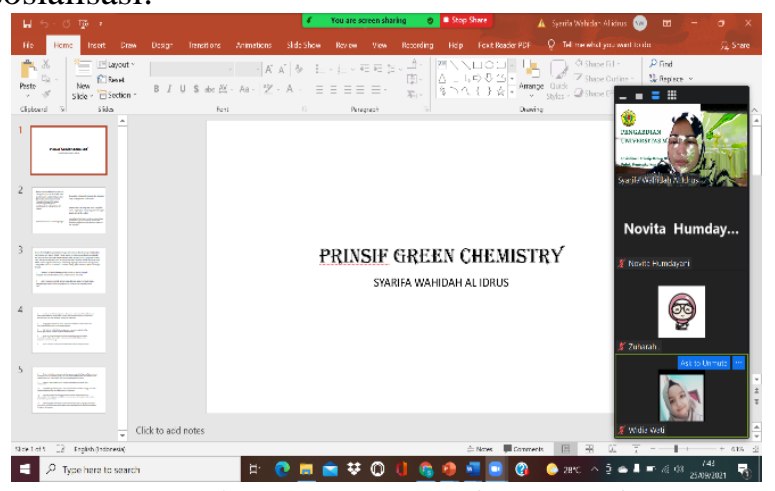

Gambar 1. Penyampaian materi

\section{Diskusi}

Pada tiap materi yang disampaikan, peserta dapat berdialog dan berdiskusi dengan tim Pengabdian.

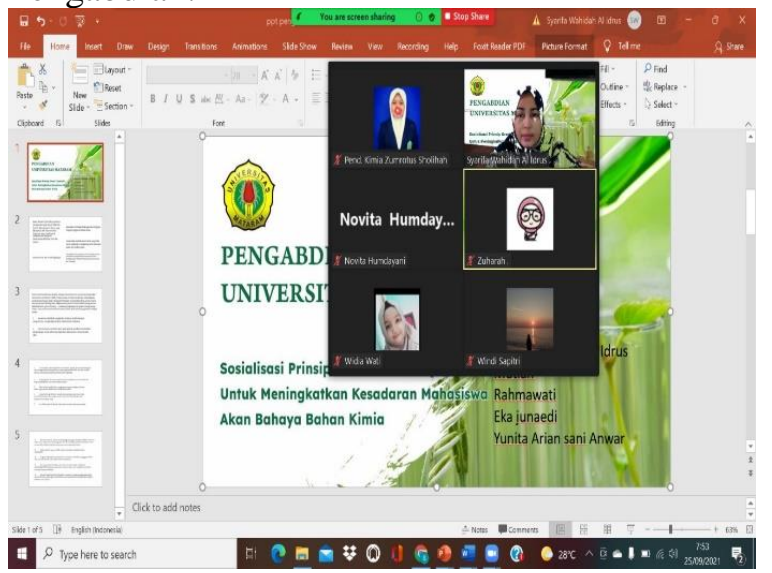

Gambar 2. Proses diskusi setelah penyampaian materi

3. Praktek penerapan prinsip green chemistry

Peserta diminta untuk melakukan praktek/latihan penerapan prinsip green chemistry.
e-ISSN : 2715-2537

p-ISSN : 2715-2545

Praktek dilakukan dengan cara meminta peserta meyiapkan panduan praktikum yang sedang digunakan pada semester ini dan diminta menganalisa bahan bahan pada panduan tersebut. Kalau bahan bahan yang ada berbahaya, peserta diminta untuk memodifikasi dengan prinsip green chemistry. Peserta akan dikelompokkan berdasarkan tingkat semester. Hasil modifikasi panduan praktikum akan dikumpulkan kepada tim pengabdian.

\section{Hasil dan Pembahasan}

Hasil penelusuran kemampuan awal peserta sosialisasi tentang prinsip green chemistry, sebagian kecil sudah pernah membaca tapi belum memahami. Sebagian besar peserta belum pernah membaca dan mendengar tentang prinsip green chemistry. Lemahnya literasi atau membaca tentang green chemistry akan membuat rendahnya pengetahuan peserta tentang prinsip green chemistry. Literasi merupakan salah satu tolak ukur penilaian kemampuan individu dalam menerapkan pengetahuan tentang konsep green chemistry dalam kehidupan sehari-hari. Mengukur kemampuan awal atau bisa disebut dengan prior knowledge (PK) merupakan salah satu langkah penting didalam proses belajar, kemampuan awal harus diamati sebelum peroses pembelajaran dilakukan. Mahasiswa akan menyaring konsep baru yang akan dipelajari melalui kemampuan awal atau PK.

Rendahnya kemampuan awal mahasiswa disebabkan kurang mengkaji reaksi-raksi kimia dan sifat-sifat bahan kimia yang digunakan sebagai pereaksi atau pelarut, sehingga mahasiswa tidak memahami bahaya limbah praktikum terhadap keberlanjutan lingkungan. Limbah praktikum di laboratorium berpotensi menimbulkan pencemaran lingkungan. Grafik pengetahuan awal dan setelah sosialisasi bisa dilihat pada gambar 3 .

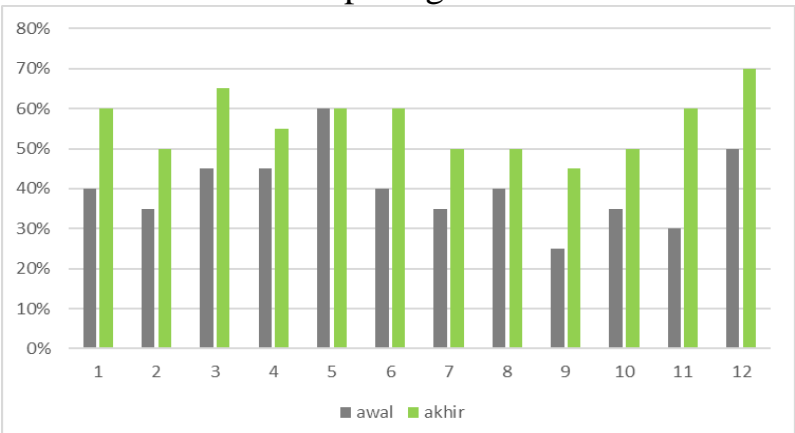

Gambar 3. Gambaran pengetahuan green chemistry sebelum dan setelah sosialisasi 
Idrus et al, Jurnal Pengabdian Masyarakat Sains Indonesia 2021, 3 (2):246-252 DOI: https://doi.org/10.29303/ipmsi.v3i2.135

Berdasarkan gambar 3., pengetahuan tentang green chemistry peserta mengalami kenaikan setelah mereka mengikuti sosialisasi. Proses sosialisasi yang dilakukan dengan maksud mengenalkan kepada peserta tentang prinsip green chemistry. Prinsip green chemistry merupakan suatu konsep pendekatan kimia yang sangat penting dan dibutuhkan oleh mahasiswa calon guru kimia. Calon guru kimia yang akan menjadi guru akan memberikan pemahaman langsung ke siswa tentang kesadaran lingkungan. Hal ini harus dilakukan untuk mengikuti agenda pembangunan berkelanjutan.

Agenda pembangunan berkelanjutan yang dicetuskan oleh Word Commision on Environment and development (WCED), yaitu Komisi Lingkungan Hidup Sedunia dan pembangunan telah mensyaratkan bahwa dalam pembangunan harus meningkatkan produksi dengan cara yang ramah lingkungan. Selain itu semua proses yang dilakukan harus memberikan kesempatan yang merata dan adil bagi semua orang. Perhatian ketaraf hidup masyarakat harus dengan cara yang tidak merusak lingkungan hidup. Pembangunan diharapkan mengacu kepada pembangunan yang berwawasan lingkungan dan berkelanjutan menuju terbentuknya green globe (bumi yang hijau/ lestari).

Green globe akan terbentuk bisa dimulai dari bidang Pendidikan. Hal ini bisa dilakukan dengan mengintegrasikan prinsip green chemistry pada bidang Pendidikan. Salah satu cara yang dilakukan dengan memulai mengenalkan prinsip green chemistry ini pada mahasiswa calon guru. Guru sebagai salah satu masyarakat akademik diharapkan mampu untuk mengembangkan ilmu pengetahuan dan teknologi serta pemecahan berbagai permasalahan yang dihadapi masyarakat (Santosa, 2007), termasuk masalah lingkungan. Prinsip green chemistry bisa dijadikan sebagai salah satu upaya dasar untuk sadar lingkungan.

Prinsi-prinsip green chemistry yang bisa diterapkan terdiri dari 12 prinsip, yaitu:

\section{Mencegah timbulnya limbah dalam proses}

Prinsip ini menegaskan bahwa proses pencegahan Lebih baik daripada mengatasi limbah yang timbul setelah proses sintesis, karena biaya pembersihan limbah sangat besar dan hasil yang tidak maksimal.

\section{Mendesain produk bahan kimia yang aman}

Desain produk yang aman bisa dilakukan jika memilki pengetahuan mengenai struktur kimia. Hal
e-ISSN $: 2715-2537$

p-ISSN : 2715-2545

ini disebabkan seseorang dapat mengkarakterisasi toksisitas dari suatu molekul. Target utamanya adalah mencari nilai optimum agar produk bahan kimia memiliki kemampuan dan fungsi yang baik akan tetapi juga aman (toksisitas rendah). Hal yang biasa dilakukan adalah dengan mengganti gugus fungsi atau dengan cara menurunkan nilai bioavailability.

\section{Mendesain proses sintesis yang aman}

Proses sintesis yang aman jika desain yang digunakan aman dan menghasilkan bahan kimia yang tidak beracun terhadap manusia dan lingkungan. Hal tersebut dapat dilakukan dengan meminimalkan paparan atau meminimalkan bahaya pada proses sintesis yang menggunakan bahan kimia tersebut.

\section{Menggunakan bahan baku yang dapat terbarukan}

Pada proses industri Penggunaan bahan baku yang dapat diperbarui lebih disarankan daripada menggunakan bahan baku yang tak terbarukan didasarkan pada alasan ekonomi. Bahan baku terbarukan biasanya berasal dari produk pertanian atau hasil alam, sedangkan bahan baku tak terbarukan berasal dari bahan bakar fosil seperti minyak bumi, gas alam, batu bara, dan bahan tambang lainnya.

\section{Menggunakan katalis}

Katalis berfungsi mempercepat proses reaksi. Penggunaan katalis memberikan hasil yang meningkat, serta mampu mengurangi produk samping serta menghemat energi dan waktu. Katalis dapat meningkatkan selektifitas, mengurangi penggunaan zat kimia dan mengurangi penggunaan energi.

\section{Menghindari derivatisasi dan modifikasi sementara dalam reaksi kimia \\ Mengurangi derivatisasi yang tidak} diperlukan seperti penggunaan gugus pelindung, proteksi/deproteksi pada proses fisika ataupun kimia. Proses derivatisasi memerlukan tambahan reagen yang nantinya akan memerlukan biaya tinggi dan memperbanyak limbah.

\section{Memaksimalkan atom ekonomi}

Metode sintesis harus meminimalkan bahan dasar dan meningkatkan produk. Konsep atom ekonomi ini mengevaluasi sistem terdahulu yang 
Idrus et al, Jurnal Pengabdian Masyarakat Sains Indonesia 2021, 3 (2):246-252 DOI: https://doi.org/10.29303/ipmsi.v3i2.135

hanya melihat rendemen hasil sebagai parameter untuk menentukan suatu reaksi efektif dan efisiens tanpa melihat seberapa besar limbah yang dihasilkan dari reaksi tersebut. Atom ekonomi disini digunakan untuk menilai proporsi produk yang dihasilkan dibandingkan dengan reaktan yang digunakan. Jika semua reaktan dapat dikonversi sepenuhnya menjadi produk, dapat dikatakan bahwa reaksi tersebut memiliki nilai atom ekonomi $100 \%$.

\section{Menggunakan pelarut yang aman}

Pelarut yang aman sangat dibutuhkan pada setiap proses kimia. Penggunaan bahan kimia sebagai pelarut harus diminimalkan atau menggunakan konsentrasi yang rendah sehingga tidak menimbulkan limbah yang berbahaya. Penggunaan pelarut memang sangat penting dalam proses sintesis, misalkan pada proses reaksi, rekristalisasi, sebagai fasa gerak pada kromatografi, dan lain-lain. Penggunaan yang berlebih akan mengakibatkan polusi yang akan mencemari lingkungan. Alternatif lain adalah dengan menggunakan beberapa tipe pelarut yang lebih ramah lingkungan seperti ionic liquids, flourous phase chemistry, supercritical carbon dioxide, dan"biosolvents". Selain itu ada beberapa metode sintesis baru yang lebih aman seperti reaksi tanpa menggunakan pelarut ataupun reaksi dalam media air.

\section{Meningkatkan efisiensi energi dalam reaksi}

Energi yang digunakan dalam suatu proses kimia harus mempertimbangkan efek terhadap lingkungan dan aspek ekonomi. Jika dimungkinkan reaksi kimia dilakukan dalam suhu ruang dan menggunakan tekanan.Penggunaan energi alternatif dan efisien dalam sintesis dapat dilakukan dengan menggunakan beberapa metode baru diantaranya adalah dengan menggunakan radiasai gelombang mikro (microwave), ultrasonik dan fotokimia.

\section{Mendesain bahan kimia yang mudah terdegradasi \\ Bahan kimia harus didesain dengan} mempertimbangkan aspek lingkungan, oleh karena itu suatu bahan kimia harus mudah terdegradasi dan tidak terakumulasi di lingkungan.Seperti sintesis biodegradable plastik, bioderadable polimer, serta bahan kimia lainya.

\section{e-ISSN : 2715-2537 \\ p-ISSN : 2715-2545 \\ 11.Penggunaan metode analisis secara langsung untuk mengurangi polusi}

Metode analisis yang dilakukan secara realtime dapat mengurangi pembentukan produk samping yang tidak diinginkan.Ruang lingkup ini berfokus pada pengembangan metode dan teknologi analisis yang dapat mengurangi penggunaan bahan kimia yang berbahaya dalam prosesnya.

\section{Meminimalisasi potensi kecelakaan}

Bahan kimia yang digunakan dalam reaksi kimia harus dipilih sedemikian rupa sehingga potensi kecelakaan yang dapat mengakibatkan masuknya bahan kimia ke lingkungan, ledakan dan api dapat dihindari.

Setelah proses sosialisai dilakukan, mahasiswa diminta untuk berdiskusi dan bertanya kepada pemateri tentang hal hal yang belum dipahami. Pada proses ini mahasiwa terlihat sangat antusias. Mahasiswa mencoba menceritakan hal hal yang pernah dilakukan ternyata sudah berbasis green chemistry. Dari semua peserta sebagaian besar sudah pernah menggunakan katalis pada laboratorium. Peserta yang berasal dari semester I belum pernah menggunakan katalis.

Untuk peserta yang berasal dari mahasiswa semester III,V dan VII, lebih cepat memahami tentang prinsip green chemistry karena mereka sudah sangat paham dengan kerja di laboratorium. Kondisi ini menyebabkan mereka mulai berfikir apa yang mereka lakukan selama ini sudah sesuai prinsip green chemistry atau tidak. Mahasiswa semester V dan VII pernah melakukan praktikum secara offline setelah itu terkendala pandemic, jadi praktikum dilakukan secara online. Semester I dan III, belum pernah mengikuti praktikum offline selama perkuliahan.

Pengalaman praktikum online menyebabkan mahasiswa semester V dan VII lebih paham akan bahaya zat kimia. Dan mencoba menindaklanjuti pemahaman tentang green chemistry pada petunjuk praktikum yang pernah diperoleh. Proses sosialisasi ini ditindak lanjuti dengan membagi kelompok berdasarkan semester dan meminta mereka untuk memodifikasi petunjuk praktikum yang saat ini mereka lakukan menjadi berbasis green chemistry. Modifikasi dengan tujuan membuat petunjuk praktikum yang ada menjadi lebih aman untuk praktikan dan lingkungan.

Hasil modifikasi petunjuk praktikum, menunjukkan bahwa peserta sudah mulai memahami tentang prinsip green chemistry. Peserta 
Idrus et al, Jurnal Pengabdian Masyarakat Sains Indonesia 2021, 3 (2):246-252 DOI: https://doi.org/10.29303/ipmsi.v3i2.135

yang berasal dari mahasiswa semester 1 dan 2 bisa memodifikai dengan menunjukkan penambahan katalis pada petunjuk praktikum. Sementara peserta yang berasal dari mahasiswa semester V dan VII, bisa mengidentifikasi zat zat yang berbahaya dalam praktikum dan mencoba memberi saran pengganti zat yang aman.

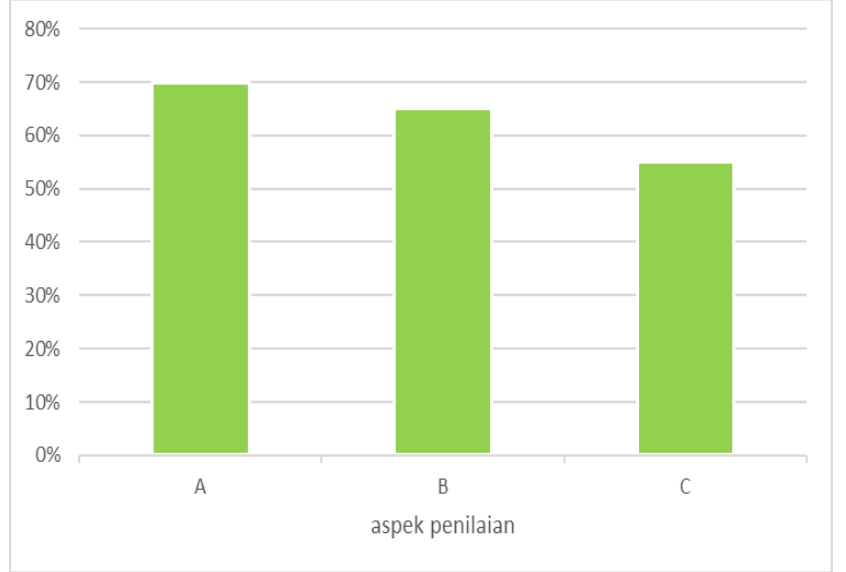

Gambar 4. Gambaran pengetahuan prinsip green chemistry selama proses.

Berdasarkan gambar 4, sebanyak 14 orang mahasiswa bisa mengidentifikasi ada atau tidak prinsip green chemistry dalam suatu penuntun praktikum (A). sebanyak 70\%. Hal ini disebabkan hampir semua peserta bisa mengidentifikasi setiap penggalan panduan yang diberikan. Dan kebanyakan penggalan yang diberikan mengunakan katalis. Sebanyak $65 \%$ peserta paham bahwa zat yang digunakan dalam petunjuk praktikum berbahaya (B). Sebagian besar yang mampu mengidentifikasi adalah mahasiswa semester tinggi. Peserta yang mampu memodifikasi zat pengganti yang lebih aman sebanyak 55\% (C). Penilaian selama proses ini menunjukkan mahasiswa mengikuti kegiatan sosialisasi dengan baik, sehingga untuk semua aspek, jumlah mahasiswa yang paham diatas $50 \%$.

Pengetahuan yang didapat saat sosialisasi menjadi pengetahuan awal tentang prinsip green chemistry. Pengetahuan awal ini bisa dijadikan acuan dalam melaksanakan kegiatan yang melibatkan zat kimia dan energy dalam kehidupan. Sebagai calon guru, peserta diharapkan mampu untuk mengembangkan ilmu pengetahuan dan teknologi serta pemecahan berbagai permasalahan yang dihadapi masyarakat (Santosa, 2007). Sebagai calon guru, harapannya peserta dapat menerapkan prinsip green chemistry dalam pembelajaran. Karena pembelajaran kimia dengan
e-ISSN $: 2715-2537$

p-ISSN : 2715-2545

penekanan sikap peduli lingkungan sangat diperlukan sejak awal (Sudarmin, 2013).

Akhir proses pengabdian ini peserta diberikan lagi soal yang berkaitan dengan prinsip green chemistry. Sebagian peserta memiliki nilai yang lebih tinggi dibandingkan nilai diawal sosialisasi (gambar 3).

\section{Kesimpulan}

Kegiatan pengabdian sosialisasi Prinsip Green Chemistry mendapat respon yang cukup baik dari peserta mahasiswa calon guru kimia. Keadaan ini dapat dilihat dari kehadiran peserta yang hampir mencapai $80 \%$. Peserta terdiri dari mahasiswa semester I, III, V dan VII. Soaialisasi ini menjadi tahap awal pengenalan prinsif green chemistry pada mahasiswa calon guru kimia. Sebelum sosialisasi dilakukan rata rata peserta semester I dan III, belum pernah mengenal prinsif green chemistry. Setelah sosialisasi, sebagian peserta sudah mengenal dan dapat menunjukkan prinsif green chemistry pada petunjuk praktikum yang sedang dijalankan. Sementara untuk peserta semester V dan VII sudah mampu mengidentifikasi zat zat kimia berbahaya dalam petunjuk praktikum dan bisa memberikan alternative zat pengganti yang lebih aman.

\section{Saran}

Berdasarkan hasil yang diperoleh perlu ditindaklanjuti lebih dalam lagi dengan pelatihan penyusunan petunjuk praktikum berbasis green chemistry.

\section{Ucapan Terima Kasih}

Penulis mengucapkan terima kasih kepada Universitas Mataram yang telah menfasilitasi kegiatan pengabdian ini. Kemudian termakasih pula peulis sampaikan kepada dosen dan mahasiswa Program Studi Pendidikan Kimia, FKIP, Universitas Mataram yang telah mendukung kegiatan ini sehingga berjalan dengan baik.

\section{Daftar Pustaka}

Al Idrus, S.W, Purwoko, AA, Hadisaputra, S dan Junaedi, E (2020). Analisis Kemampuan Awal Konsep Green 
Idrus et al, Jurnal Pengabdian Masyarakat Sains Indonesia 2021, 3 (2):246-252 DOI: https://doi.org/10.29303/ipmsi.v3i2.135

Chemistry Sebagai Upaya

Meningkatkan Kreatifitas Mahasiswa

Dalam Praktikum Kimia Lingkungan.

J. Pijar MIPA, Vol. 15 No.3

Anastas, P. T., Kirchhoff, M. M., \& Williamson, T. C. (2001). Catalysis as a foundational pillar of green chemistry. Applied Catalysis A: General, 221(1-2).

Astute, A.P.(2015). Penerapan pendekatan konstruktiisme berorientasi green chemistry untuk meningkatkan keterampilan berfikir kritis dan hasil belajar kimia SMA. Jurnal Pendidikan Sains, Vol. 2. No.2. 54

Aubrecht, K. B., Padwa, L., Shen, X., \& Bazargan, G. (2015). Development and Implementation of A Series of Laboratory Field Trips for Advanced High School Students to Connect Chemistry to Sustainability. Journal of Chemical Education, 92(4), 631-637.

Burmeister, M., Rauch, F., \& Eilks, I. (2012). Education for Sustainable Development (ESD) and chemistry education. Chemistry Education Research and Practice, 13(2), 59- 68

Haack J.A., Hutchison, J.E., Kirchoff, M.M., \& Levy, I.J. (2005). Going green: Lecture assignments and lab experiences for the college curriculum. Journal of Chemical Education, 82(7), 974-976.

Karpudewan, M., Roth, W. M., \& Ismail, Z. (2015). The effects of "Green Chemistry" on secondary school students' understanding and motivation. The AsiaPacific Education Researcher, 24(1), 3543.

Santoso, Soegeng. (2007). Kiat dan Strategi Menulis Karya Ilmiah. Universitas Negeri Jakarta. Makalah disampaikan pada pelatihan penulisan Karya Tulis Ilmiah Bagi Dosen-dosen PPSD FIP UNY.

Sudarmin (2013), kemampuan generic sains kesadaran tentang skala sebagai wahana mengembangkan praktikum kimia organic berbasis green chemistry. Jurnal No. 1,18-20. 